\title{
THE ROLES OF PUBLIC FIGURE IN FOOD BRANDING: A CASE STUDY
}

\author{
Handayani Rahayuningsih ${ }^{1}$, Anik Nuryani ${ }^{2}$ \\ Management, Universitas Gadjah Mada \\ Yogyakarta, Indonesia \\ handayani.rahayuningsih@ugm.ac.id, anik.nuryani@ugm.ac.id
}

\begin{abstract}
To make the experiences of visiting tourist destination become tangible, tourists are inclined to bring some souvenirs for their family and friends. Such big target market is enough reason to make businesses which provide souvenirs such as goods and foods in the tourist destinations. At the moment, there is an ongoing trend in Indonesia which uses celebrity or famous public figures' names as a part of the souvenirs' marketing appeal. Malang Strudel, Jogja Scrummy, and Surabaya Snowcake are a few examples of foods, especially pastries, as souvenir that are specifically marketed for the visitors of a particular city, and use famous actors and actress' as owner and their brand ambassadors. The construction of foods identity and products branding of food as souvenir were the focus of this research. The data were collected through interview, documentation, and observation. The results indicate that public figures are extremely important in creating the identity of food as the souvenir of a particular city, although the product itself is not originally from the city. Moreover, tourists who buy the food as souvenir were influenced by the public figures' name.
\end{abstract}

Keywords: souvenir; food identity; food branding; marketing; public figure

\section{INTRODUCTION}

To make the experiences of visiting tourist destination become tangible, tourists are inclined to bring some souvenirs for their family and friends. Such big target market is enough reason to make businesses which provide souvenirs in tourist destination such as goods and foods in the destination. Love \& Sheldon (1998) conducted study of various types of souvenirs in tourist destinations.

There are several studies that discuss tourists' motivation in purchasing souvenirs (Kim \& Littrell, 2001; Wilkins (2011). Kim \& Littrell (2001) stated that tourists purchase souvenirs for themselves dan as a gift for family and colleagues. Furthermore, the desire to purchase a souvenir is influenced by previous travel experience (Kim \& Littrell, 2001). Souvenirs are important to tourists as an evidence, a memento, or a gift (Wilkins, 2011). Another study about souvenirs in relation with gift-giving behavior for self and others 
Jurnal Manajemen Bisnis, Vol 10. No.1, Maret 2019, E-ISSN:2622-6308 P-ISSN:2086-8200

Website: http://journal.umy.ac.id/index.php/mb

DOI:10.18196/mb.10170

was conducted by Ward \& Tran (2007).

Swanson \& Horridge (2002) said that tourists have expectations for retailers. Tourists typically bring home souvenirs assortments of souvenirs ranging from local foods and fine jewelry. Tourists take into account several factors when selecting souvenirs to buy, such as the motive or design of the product, and the craftsperson's reputation or image. It is also emphasized that the store location should be in high pedestrian traffic areas. The craftsperson's reputation or image is essential as it implies a sense of trust to the quality of the products. Mittilä \& Lepistö (2013) agreed that artists or craftsmen are extremely important to the construction of the identity of a place.

Purchasing a souvenir is a part of shopping activities that tourists can do in the destination. Kent, Shock, and Snow (1983) made an argument that shopping is almost always included in the activities that tourists participated in while traveling. This finding is supported by Timothy and Butler (1995) who said that shopping is the preferred activity in many tourist destinations.

At the moment, there is an ongoing trend in Indonesia which uses celebrity or famous public figures' names as a part of the souvenirs' marketing appeal. Malang Strudel, Jogja Scrummy, and Surabaya Snowcake are a few examples of foods, especially pastries, as souvenir that are specifically marketed as souvenir for the visitors of a particular city, and use famous actors and actress' as owner and their brand ambassadors. Brand equity has a significant impact on customer's brand choice intention (Lu, Gursoy, \& Lu, 2015). Furthermore, Lu, Gursoy, \& Lu (2015) said that a strong brand image enables customers to better recognize and understand intangible products and services. That's why this study need to be done in order to examine the roles of public figures in food branding, especially food as souvenir.

\section{METHODS}

This case study can be considered as research strategy because it involves the investigation of multiple cases in order to arrive to conclusion on the role of public figures in food branding. The construction of foods identity and products branding of food as souvenir were the focus of this research.

The data were obtained through interviews, observation, and documentation. 
Jurnal Manajemen Bisnis, Vol 10. No.1, Maret 2019, E-ISSN:2622-6308 P-ISSN:2086-8200

Website: http://journal.umy.ac.id/index.php/mb

DOI:10.18196/mb.10170

Respondents were selected through purposive method to obtain credible subjects, in accordance with the predetermined criteria (Strauss \& Corbin, 1990). In this study, respondents were the informants from both the management of the food brands, and tourists or visitors who bought the products as souvenir.

All interviews conducted on the respondents were recorded and transcribed. The interviews were semi-structured. In addition, secondary data consisting of marketing material and online information about different research locations were also collected.

The data were then analyzed through the descriptive method. Collected data would be organized into several categories and patterns in order to see the correlation between the data, in addition to trianggulation data.

\section{THEORY}

Tourist shopping and souvenirs have significant influence on tourism retailing and may represent the best and easiest way to experience local culture ( $\operatorname{lin} \&$ Mao, 2015). Food-based products may be established as part of regional cuisine and may be linked to the identity of the tourism area (Hashimoto \& Telfer, 2013). Moreover, Gordin \& Trabskaya (2013) argued that the basis for a gastronomic brand can be traced to the cultural and historic traditions of the region. Food souvenirs related to local culture, in this case local food used as souvenir.

The link between a city's food brand image and behavioral intention can be considered from several perspectives (Tsai \& Wang, 2016). The social perspective explains a customer's tendency to use brands with favorable images in social settings (Tsai \& Wang, 2016). Graeff (1998) found that brand image can significantly influence a customer's behavioral intention, especially when the brand will be used publicly or for social purposes. A positive brand image will make marketing program would be liked by the customers and be able to produce unique associations in customers' retention (Schiffman \& Kanuk, 2010). Forming a positive brand image is becoming increasingly important to be owned by a company because of brand image is often referenced in the psychological aspects of the image or impression that is built into the subconscious of consumers through the expectations and experience of a product or service (Pujadi, 2010).

Actually, a positive brand image it's not only important for a product or service, but 
Jurnal Manajemen Bisnis, Vol 10. No.1, Maret 2019, E-ISSN:2622-6308 P-ISSN:2086-8200

Website: http://journal.umy.ac.id/index.php/mb

DOI:10.18196/mb.10170

also a place. Furthermore, Mittilä \& Lepistö (2013) said that artists, in this case a group of stakeholder in a destination, are extremely important to the construction of the identity of a place or place branding; unfold as stories, artifacts and atmosphere as well as entrepreneurs.

\section{THE CASE}

The research took place in the three cities where each food brand marketed their products as souvenir of its city, Malang (Malang Strudel), Yogyakarta (Jogja Scrummy), and Surabaya (Surabaya Snowcake). Each of this brand had a public figure or famous actors and actress (celebrities) as owner and their brand ambassador, namely Teuku Wisnu for Malang Strudel, Dude Herlino for Jogja Scrummy, and Zaskia Sungkar for Surabaya Snowcake. They was selected as the research location because those three food brands are the first food brands in Java which use famous celebrities, actors and actress' name to promote their products and name themselves as a souvenir of a particular city. In this case, it needs to be noted that the cities are not the hometowns of the celebrities, nor that the product branded as a specialty souvenir for the city is the traditional food originated from the city.

\section{FOODS IDENTITY}

\section{Malang Strudel}

Strudel is a type of layered pastry with a filling made from fruits. It became popular in Austria in the 18th century. Although Strudel is an Austrian cuisine, it also is common in many European countries especially Germany. In Germany, there is a favorite strudel with apple filling which is called apfelstrudel (https://malangstrudel.com/).

To relate the food's origin story with the city it is marketed to, there needs to be a background story on the product. In the case of Malang Strudel, it is told that when Teuku Wisnu and his family went to Europe for vacation, they had a tasty strudel and they fell in love with the taste, and thus, Teuku Wisnu was inspired to make strudel in Malang. This product is perfectly marketed in Malang, because one of the city's most famous specialties is the apples. Eventually, the brand develops the strudel and offers other fillings of fruits besides apple. The product is marketed only in Malang to maintain its reputation as a specialty brand for the city. 
Jurnal Manajemen Bisnis, Vol 10. No.1, Maret 2019, E-ISSN:2622-6308 P-ISSN:2086-8200

Website: http://journal.umy.ac.id/index.php/mb

DOI:10.18196/mb.10170

The business was managed by the actor and partners, as well as working in cooperation with local businessmen. The management said that the strudels are produced using local ingredients. The taste is also adjusted with local taste to make the products accepted by local customers.

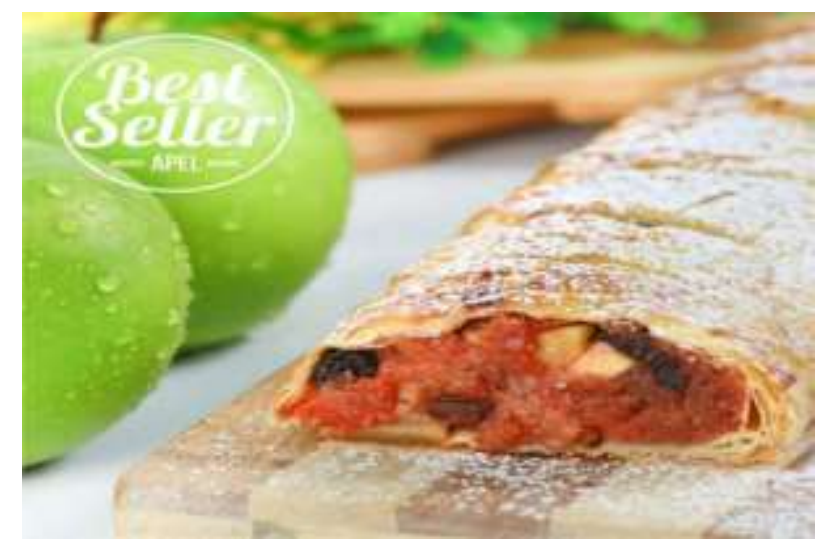

Picture 1: Malang Strudel with Apple Filling

Source: malangstrudel.com

\section{Jogja Scrummy}

The word "scrummy" is a blend of "scrumptious" and "yummy" which means delicious (yourdictionary.com/scrummy). A respondent from Jogja Scrummy management said that their product is a new innovation from steamed brownies. While the usual brownies only have one layer, Jogja Scrummy modified the regular brownie with layers of puff pastry. The layers are an essential characteristic of this product. In some varians, Jogja Scrummy innovate the brownie into two layers with cream filling between the layers. These cakes are produced by Dude Herlino and partners including one from Yogyakarta. As is the case with Malang Strudel, the product is specifically marketed as souvenir from Yogyakarta.

The back story of Jogja Scrummy is that Dude Herlino often visited Yogyakarta either for his acting job, or for vacation, and because of that, he felt a close relationship with the city. He intended to start a business in Yogyakarta, hence, he made Jogja Scrummy.

As the product attracts many resellers and agents or services offering the product for customers in other cities, the management said that they could not take responsibility when problems occurred. The customers are expected to visit the official outlet in Yogyakarta if they want their products guaranteed. The management's decision not to offer services outside of Yogyakarta is a part of their effort in inviting more visitors to Yogyakarta 
and contribute to its tourism development.

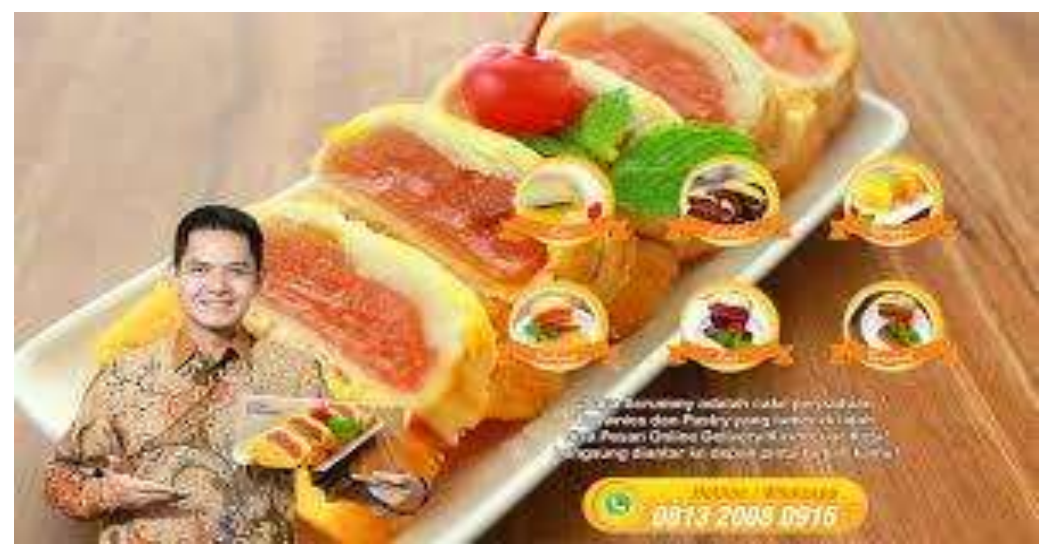

Picture 2: Jogja Scrummy

Source: jogjascrummy.com

\section{Surabaya Snowcake}

The management of Surabaya Snowcake said that their products are a modification form of Spikoe. Spikoe is a cake from Surabaya that has three layers, in which the first and third layers are dark brown, and the midle layer is light brown or yellow. Surabaya Snowcake modified it into three layers, where the first and third layers are puff pastry and the second layer was a regular cake modified into various tastes. The name Snowcake refers to the plenty icing sugar that tops the cake, which makes it seem like snow. Zaskia Sungkar, the actress, acts as the brand ambassador and works with local businessmen to build the company. The promotion states that because the weather in Surabaya is hot, Zaskia wanted to bring "snow" to Surabaya to make it cooler.

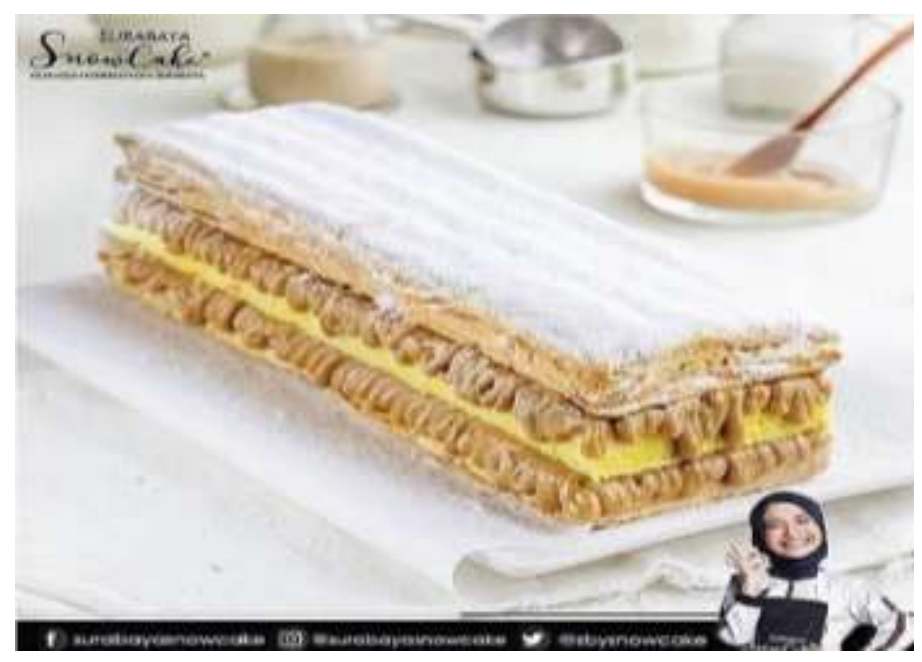

Picture 3: Caramel Varian from Surabaya Snowcake

Source: Instagram @surabayasnowcake

Article history : received 13 July 2019, revised -, accepted 17 July 2019 
Jurnal Manajemen Bisnis, Vol 10. No.1, Maret 2019, E-ISSN:2622-6308 P-ISSN:2086-8200

Website: http://journal.umy.ac.id/index.php/mb

DOI:10.18196/mb.10170

\section{THE ROLE OF PUBLIC FIGURES IN FOOD BRANDING}

\section{Malang Strudel}

Malang Strudel is a brand from PT Khasanah Ukhuwah Bertiga. One of the owners of the company is Teuku Wisnu, an actor. The result of the interview with a respondent from the management shows that Teuku Wisnu takes an active part in the promotion of Malang Strudel. In the opening ceremony, he would meet and greet the costumers. Moreover, he did not hesitate to serve the customers directly. He also spent time meeting with the reporters and travel/culinary bloggers/vloggers to promote Malang Strudel. In his social media, Teuku Wisnu (TW) frequently posted stories about Malang Strudel. There is even a special feature called "Catatan TW" (TW's notes) in the Malang Strudel's website that talks about Malang Strudel from TW's point of view.

As a public figure, Teuku Wisnu has a lot of fans, followers in social media, and access to mass media. This means that Teuku Wisnu is the best choice to become the icon of Malang Strudel compared to other owners. Respondents who preferred Malang Strudel to other souvenirs said that the product was highly popular in social and mass media. Certainly, this result cannot be separated from Teuku Wisnu's role as a public figure. On the other hand, other respondents said that Teuku Wisnu was not the reason they bought Malang Strudel, and other respondents did not even know that Malang Strudel was owned by Teuku Wisnu. These respondents simply buy Malang Strudel because they know about its hype from their friends, directly, or from social media. Nevertheless, Teuku Wisnu's role is undeniably essential in promoting Malang Strudel in social media.

\section{Jogja Scrummy}

Jogja Scrummy is one of the brands of PT Berkah Ukhuwah Berlapan. Besides Jogja Scrummy with Dude Herlino (actor) as the brand ambassador, the company also owns another brand named Bogor Raincake with Shireen Sungkar (actress) as the brand ambassador. Jogja Scrummy is not only owned by Dude Herlino, as he also works with local Yogyakartan businessmen and other partners.

From the interview with the management, as the brand ambassador and one of Jogja Scrummy owners, Dude Herlino rarely visited the business due to his busy schedule as an actor. Dude only visits Jogja Scrummy during special events, such as the brand launching, meet and greet with the customers, press conference, and other promotion events. To 
Jurnal Manajemen Bisnis, Vol 10. No.1, Maret 2019, E-ISSN:2622-6308 P-ISSN:2086-8200

Website: http://journal.umy.ac.id/index.php/mb

DOI:10.18196/mb.10170

promote Jogja Scrummy, the company often uses pictures of Dude Herlino in banners, leaflets, product packaging, etc. In his social media, Dude Herlino, who has a massive amount of followers, frequently promotes Jogja Scrummy. As a result, his followers are familiar with the product and tend to spread the word to their friends and families.

Most of Jogja Scrummy's customers said that Dude Herlino has a big role in promoting the product and make people aware about Jogja Scrummy. They were aware that Jogja Scrummy became well-known as a choice of souvenir from Jogja because of the famous actor, Dude Herlino, promoted the product. Although most of the respondents knew Jogja Scrummy because of Dude Herlino, their decision to buy Jogja Scrummy was not because of the actor's name. Some of them said that Jogja Scrummy was so popular in social media that they became curious about the taste. Some of the respondents who were frequent customers said that the taste is the reason they keep coming back to Jogja Scrummy.

\section{Surabaya Snowcake}

Surabaya Snowcake is one of brands from Jannah Corporation (J.Corp). One of its Chief Executive Officers is Zaskia Sungkar, an actress. In addition to Surabaya Snowcake, the company also owns Medan Napoleon with Irwansyah (actor) as brand ambassador, Vini Vidi Vici with Vidi Aldiano (singer) as brand ambassador, Bandung Makuta with Claudia Chyntia Bella (actress), and many more.

The interview with a respondent showed that Zaskia Sungkar rarely visits Surabaya Snowcake. She comes when there are special occasions like brand and outlet launching or promotion event, which is not much different from that done by Teuku Wisnu and Dude Harlino. Zaskia Sungkar also took part in meet and greet sessions with customers and did not hesitate to serve them directly. She also meets reporters and culinary/travel bloggers/vloggers to promote Surabaya Snowcake. In her social media, Zaskia Sungkar frequently posts stories to promote Surabaya Snowcake. On the official pictures of the Surabaya Snowcake brand, there is always picture of Zaskia Sungkar. She is even nicknamed the "Snow Queen" by the company.

A respondent said that Zaskia Sungkar's popularity as an actress was used by the brand to enter the market. Furthermore, respondents argued that many people are easily interested to Zaskia Sungkar's business, including what they do, what they wear, what they eat, etc. because she is well-known. Everything she wears would look beautiful, and 
Jurnal Manajemen Bisnis, Vol 10. No.1, Maret 2019, E-ISSN:2622-6308 P-ISSN:2086-8200

Website: http://journal.umy.ac.id/index.php/mb

DOI:10.18196/mb.10170

everything she eats would look delicious. If she was an ordinary person, nobody would care. This circumstance is absolutely a good opportunity to get customers attention and to increase brand awareness. Therefore, the influence of Zaskia Sungkar as an actress and CEO has a big part in making people interested to buy Surabaya Snowcake.

Most of the respondents knew about Surabaya Snowcake from social media and bought them as souvenir. Frequent customers came back because of the taste. This proves that a famous name is not enough to maintain the popularity of a product and the customers' loyalty. Popularity is required for promotion and increasing people's awareness of the brand, yet does not guarantee the customers' maintained interest. Because the product is food, taste should not be overlooked.

\section{DISCUSSION}

Malang Strudel, Jogja Scrummy, and Surabaya Snowcake are products of innovation. Although they can be used as souvenirs, or "modern souvenir" from the city, as they marketed themselves, the fact is that none of the product is originated from the city. Nevertheless, the managements argued that even though the product is not originally from the city, it still can enrich the variety of souvenirs from the city, and therefore, allows the city's tourism to develop better. These brands argue that they want to contribute to the city's economy development through tourism by providing job opportunities to the locals.

Those three products, Malang Strudel, Jogja Scrummy, and Surabaya Snowcake, are produced by muslim entrepreneurs but not all products use Halal label from Majelis Ulama Indonesia (MUI); Indonesian council of Ulama. Only two products, Malang Strudel and Jogja Scrummy that use Halal label from MUI. Althought it's not from MUI, Surabaya Snowcake uses halal label as a form of claim that their products are safe for cunsumption by Muslims. From those two products, only Jogja Scrummy which uses that Halal label from MUI in their website. Jogja Srummy's manajemen said that they concern to two things, hygiene and halal to provide assurance to customers that their products are safe for consumption, especially for Muslims.

Another objective of this study was to enhance the understanding about the different roles of public figures, in this case actors and actresses, in the construction of food branding. As the owner and brand ambassador of their own product, the public figure' name can be 
Jurnal Manajemen Bisnis, Vol 10. No.1, Maret 2019, E-ISSN:2622-6308 P-ISSN:2086-8200

Website: http://journal.umy.ac.id/index.php/mb

DOI:10.18196/mb.10170

used to open the market and introduce their product to prospective customers at the same time. Naturally, famous figures can easily attract the attention and curiosity of the public.

The public figures' names can also be used to create story that support the product branding and marketing, such as the history of the products, the reason they make the product, and the reason they choose the city. The story is imperative in fulfilling the customers' curiosity about the products and make them believe that the idea and motivation to make the products are genuine.

Furthermore, the popularity of the public figures' names is undoubtedly significant in promoting the product. As public figures, they have a close relationship with mass media and the press, which they use to promote their products.

Finally, nowadays it is very easy to reach many people with just one click in social media, especially for the public figures with a huge amount of followers across the country. Once they post a product in social media, everyone will be instantly aware of its existence, and curious to find out more.

\section{CONCLUSIONS}

From the discussion, it can be concluded that the three products are a creation or innovation of existing products. Malang Strudel is an innovation of strudel which is famous in Europe. Jogja Scrummy is an innovation of steamed brownies that usually has only one layer. Surabaya Snowcake is an innovation of Spikoe, which is a traditional cake from Surabaya. The managements of all three brands said that they produce their products using local ingredients, by working with local businessmen, and that they only sell the product in one city. These strategies are effective in making customers and the public assume that their products are a specialty souvenir from the city although everyone knows their products are not an original or traditional food from the city.

Public figures, in this case actors and actresses, are extremely important in creating the identity of food as souvenir from a city, as they are supported by sufficient back stories and take an active part in promoting the product in both mass and social media. Tourists who buy their products are influenced by their famous names when choosing souvenirs from the city. In conclusion, their role as the owner and brand ambassador has successfully increased the brand awareness and popularity, as well as the public's interest of their products. 
Jurnal Manajemen Bisnis, Vol 10. No.1, Maret 2019, E-ISSN:2622-6308 P-ISSN:2086-8200

Website: http://journal.umy.ac.id/index.php/mb

DOI:10.18196/mb.10170

If we see the theory about food souvenirs which usually related to local culture in the form of local food, it can't be seen in this case. These three food souvenirs; Malang Strudel, Jogja Scrummy, dan Surabaya Snowcake, aren't local food from a particular city but that product become populer as food souvenir from its city. So, creative foods can become alternative food souvenirs of a destination which can be chose by tourists. It's a new argument that food souvenir is not only local food, but it can be creative food.

\section{SUGGESTIONS}

The authors have some suggestions for creative food souvenirs, local food souvenirs, and future research: (1) Creative food souvenirs need to improve products quality especially the taste to give satisfaction to the customers in order to make them repeater, not only buy cause of the trend. (2) Creative food souvenirs need to used local material more to give local taste to the products in order to gain strong position as food souvenir of particular tourist destination. (3) Local food souvenirs need to use social media, publict figure as brand ambassador, and use attractive package to promote the products in order to compete with creative food souvenirs. (4) Although this study contributes several valuable finding to literature, there is knowledge gape which worthy for further research. It is tourists' motivations to purchase creative food souvenirs.

\section{REFERENCES}

Gordin, V. \& Trabskaya, J. (2013). The role of gastronomic brands in tourist destination promotion: The case of St. Petersburg. Place Branding and Public Diplomacy. 9 (3): 189-201. doi:10.1057/pb.2013.23.

Graeff, T. R. (1998). Consumption situations and the effects of brand image on consumers' brand evaluations. Psychology Marketing, 14(1), 49-70.

Hashimoto, A. and Telfer, D. J. (2013) "Green Tourism Souvenirs in Rural Japan: Challenges and Opportunities". In J. Cave, L. Jolliffe and T. Baum (eds). Tourism Souvenirs on the Margins: Global Perspectives. Clevedon, UK: ChannelView Publications. pp. 119-131.

Kent, W.E., Shock, P.J., \& Snow, R.E. (1983). Shopping: Tourisms' unsung hero(ine). Journal of Travel Research. 21(4), 2-4.

Kim, S., and Littrell, M.A. (2001). Souvenir Buying Intentions for Self Versus Others. Annals of Tourism Research. 20 (3): 638-657.

Love, L.L., and Sheldon, P.S. (1998). Souvenirs: Messengers of Meaning. Advances in Consumer Research. 25: 170-175.

Lu, A.C.C; Gursoy, D. \& Lu, C.Y. (2015). Autenticity Perseptions, Brand Choice Article history : received 13 July 2019, revised -, accepted 17 July 2019 
Jurnal Manajemen Bisnis, Vol 10. No.1, Maret 2019, E-ISSN:2622-6308 P-ISSN:2086-8200

Website: http://journal.umy.ac.id/index.php/mb

DOI:10.18196/mb.10170

Intention: The Case of Ethnic Restaurants. International Journal of Hospitality Management. 50(2015): 36-45.

Mittilä, T. \& Lepistö, T. (2013). The role of artists in place branding: A case study. Place Branding and Public Diplomacy. 9(3), 143-153.

Pujadi, B. (2010). Studi Tentang Pengaruh Citra Merek Terhadap Minat Beli Melalui Sikap Terhadap Merek. Thesis. Semarang: Program Magister Manajemen Universitas Diponegoro.

Schiffman, L. G., \& Kanuk, L. L. (2010). Consumer Behavior. New Jersey: PearsonPrentice Hall.

Strauss, AL. \& Corbin J. (1990). Basic of Qualitative Research: Grounded Theory Procedures and Technique. Sage Publication, Newbury Park.

Surabaya Snow Cake, Oleh-Oleh Baru Khas Kota Surabaya http://kabarsurabaya.org/surabaya-snow-cake-kota-surabaya/ accessed: Sept 12th, 2017.

Swanson, K.K. \& Horrige, P.E. (2002). Tourists' Souvenir Purchase Behavior and Retailers' Awarness of Tourists' Souvenir Purchase Behavior in the Southwest. Clothing and Textiles Research Journal. 20(2), 62-76.

Timothy, D. J., \& Butler, R. W. (1995). Cross-border shopping: A North American perspective. Annals of Tourism Research. 22(1), 16-34.

Tsai, C.-T. (Simon)., \& Wang, Y.-C. (2016). Experiential Value in Branding Food Tourism. Journal of Destination Marketing $\mathcal{E}$ Management, http://dx.doi.org/10.1016/j.jdmm.2016.02.003.

Ward, C.B., and Tran, T. (2007). Consumer Gifting Behaviours: One for You, One for Me? Services Marketing Quarterly. 29(2): 1-17.

Wilkins, Hugh. 2011. Souvenirs: What and Why We Buy. Journal of Travel Research. 50(3): 239-247.

yourdictionary.com/scrummy. accessed: Sept 16th, 2017.

https://malangstrudel.com/ 